\title{
THE EFFECT OF CREATIVE DRAMA ON EMPATHIC TENDENCIES, COMMUNICATION SKILLS AND CRITICAL THINKING OF PHYSIOTHERAPY STUDENTS
}

\author{
Murat Ali Çınar, ${ }^{1}$ Elif Dinler ${ }^{2}$, Kezban Bayramlar $^{3}$, Yavuz Yakut ${ }^{4}$
}

\begin{abstract}
The empathic tendency, communication skills, and critical thinking are the professional attitude behaviors that should be in a physiotherapist. The study was planned to investigate the effects of creative drama on empathic tendencies, communication skills and critical thinking of physiotherapy students. This study was carried out in Hasan Kalyoncu University, Faculty of Health Sciences, Department of Physiotherapy and Rehabilitation between October 2017 and December 2018. 75 freshman physiotherapy students (44 women, 31 men) were included in the study. According to the results obtained from the study; there was no significant difference between empathic tendencies, communication skills and critical thinking skills of individuals in both groups ( $p>0.05$ ). When the creative drama group was compared in terms of gender, there was no significant difference between individuals' empathic tendencies, communication skills and critical thinking skills ( $p>0.05$ ). Similarly, when the control group was compared in terms of gender, there was no significant difference between individuals' empathic tendencies, communication skills and critical thinking skills $(\mathrm{p}>0.05)$. We think that this study is a preliminary study on empathic tendencies, communication skills, and critical thinking skills of physiotherapy students. Parameters such as gender, different years of education, and welfare levels can affect empathic tendency, communication skills, and critical thinking skills. There are limited studies in the literature investigating the effectiveness of creative drama in the field of health. Therefore, this work can give an idea for subsequent studies. The studies that are conducted with more patients and which are multi-centered should be done.
\end{abstract}

UDC Classification: 615.8, DOI: 10.12955/cbup.v7.1443

Keywords: Creative drama, physiotherapy, empathic tendencies, communication skills, critical thinking

\section{Introduction}

Physiotherapy education includes basic medical sciences such as physics, chemistry, biology, statistics, anatomy, physiology, as well as a number of characteristic professional skills (Lake, 2003). There are two important components of professional physiotherapy education, theoretical and practical. These components are intended to provide the student with the physical, biological and behavioral knowledge, attitudes and skills which are necessary for physical therapy applications in the classroom and laboratory. Ideal physiotherapy education should help students think differently, explain the different social concepts and values (APTA 2013).

In the paper by May et al. (1995) it is stated that the professional attitude-behavior which should be present in a physiotherapist is reliability, initiative, empathy, cooperation, communication skills, critical thinking, taking responsibility and clinical decision-making.

\section{Empathy}

Empathy is considered to be the most important component of health services in terms of patient relationships (Fields, 2011; Dal Santo, 2014). There are many definitions of empathy in literature. It is defined as a multidimensional concept that is cognitively or emotionally based in some articles, while also being defined as a combination of both concepts in recent years. (Fields 2004, Hojat 2003).

In the literature, it has been stated that an empathic attitude helps reduce the stress and anxiety of patients, resulting in better adaptation to treatment and better prognosis (Fields, 2013; Hojat, 2011; Hojat, 2013; DiMatteo, 1993).

\section{Creative drama}

Creative drama is a method that can be used in many areas. There are many drama studies from basic lessons in history, geography, mathematics, psychology to areas such as economics, politics, industry, and human relations (Fulford et al., 2001; Levent, 1999). While creative drama activities were initially

\footnotetext{
${ }^{1}$ Hasan Kalyoncu University, Faculty of Health Sciences, Physiotherapy and Rehabilitation, Gaziantep, Turkey, muratali.cinar@hku.edu.tr

${ }^{2}$ Hasan Kalyoncu University, Faculty of Health Sciences, Physiotherapy and Rehabilitation, Gaziantep, Turkey, elif.dokunlu@hku.edu.tr

${ }^{3}$ Hasan Kalyoncu University, Faculty of Health Sciences, Physiotherapy and Rehabilitation, Gaziantep, Turkey, kezbanyigiter@yahoo.com

${ }^{4}$ Hasan Kalyoncu University, Faculty of Health Sciences, Physiotherapy and Rehabilitation, Gaziantep, Turkey, yyakut@yahoo.com
} 
applied to individuals at pre-school or primary school levels, it is now applied at the undergraduate and graduate level. These activities are applied not only for educational purposes but also in many areas such as social skills and personel development etc. (Köksal, 2003). In particular, creative drama activities help individuals to think multidimensionally and to improve their ability to express themselves (Strenberg, 1998).

\section{Objectives}

In the literature, it is stated that creative drama is effective in the development of social skills (Sullivan and Fulton, 2003). Kahriman et al. (2016) stated that drama based activities affected the empathic tendencies of nurses. However, there are no studies which investigated empathic tendencies, communication skills of critical thinking of physiotherapy students and the effects of creative drama on these. Therefore, this study was planned to investigate the effect of creative drama on empathic tendencies, communication skills and critical thinking of physiotherapy students.

\section{Material and Method}

This study was carried out in Hasan Kalyoncu University, Faculty of Health Sciences, Department of Physiotherapy and Rehabilitation between October 2017 and December 2018.

75 freshman physiotherapy students (44 women, 31 men) were included in the study. The inclusion criteria were:

- Freshman physiotherapy students at Hasan Kalyoncu University

- Academic grade point average (GPA) between 2.5 and 4.00

- Volunteer for the study.

The exclusion criteria were:

- Not being a freshman physiotherapy student

- Being from another university

- Being undergraduate transfer or external transfer students

Participants were divided into two groups: the creative drama group (40 individuals) and the control group (35 individuals). The students from the creative drama group participated in creative drama activities for 4 hours a week for a total of 14 weeks. These activities consist of Preparation-Warm-up, Acting Out, Evaluation-Discussion (Table 1). An "Empathic Tendency Scale (ETS)" was used (Dökmen, Ü., 1988) to measure the potential of empathy, A "Communication Skills Scale (CSS)" was used to measure communication skills and a California Critical Thinking Disposition Inventory (CCTDI) was used to measure critical thinking for all individuals who participated in the study (Korkut and Bugay, 2014) (Table 2).

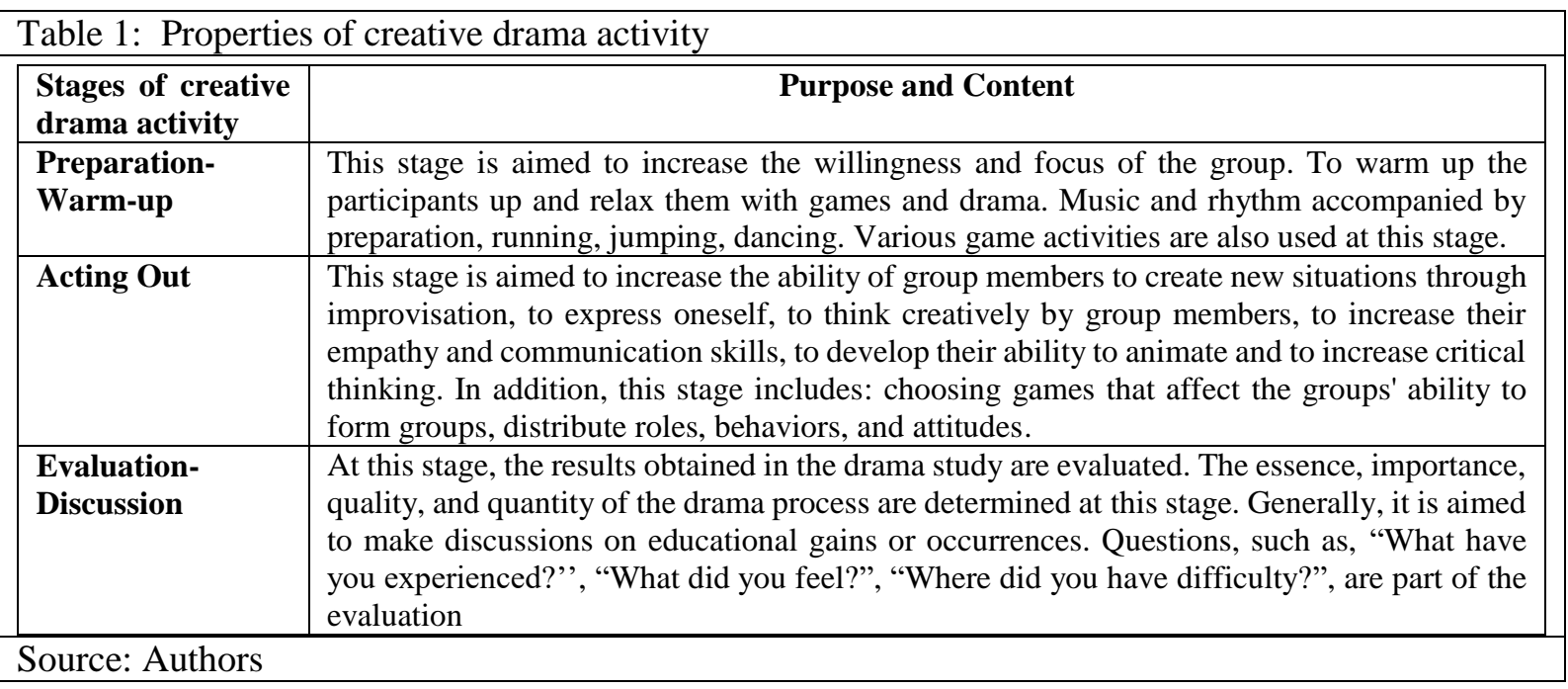

\section{Ethics Approval and Consent to Participate}

Ethical approval was obtained from Hasan Kalyoncu University, Faculty of Health Sciences Ethics Committee. Patients were informed of the nature of the study and a consent form was signed. Patients were made aware of their right to terminate their participation at any time. 


\begin{tabular}{|l|l|}
\hline Table 2: Properties of scale which are used \\
\hline $\begin{array}{l}\text { Empathic } \\
\text { Tendencies Scale } \\
\text { (ETS) }\end{array}$ & $\begin{array}{l}\text { The scale, which was prepared in order to measure the emotional sensitivity of the } \\
\text { individual in relation to the events, was developed by Dökmen (1989). The scale } \\
\text { consists of a total of 20 items and is graded as a 5-stage Likert type according to } \\
\text { "completely appropriate" or "completely inappropriate". The highest score is } 100 \\
\text { and the lowest score is 20. }\end{array}$ \\
\hline $\begin{array}{l}\text { Communication } \\
\text { Skills Scale (CSS) }\end{array}$ & $\begin{array}{l}\text { A 5-point Likert-type scale developed by Korkut (1996) and graded from "always" } \\
\text { to "never" in order to understand how individuals evaluate their communication } \\
\text { skills. The scale consists of 25 explanations. The excessive score reflects that } \\
\text { individuals' communication skills are positively evaluated. }\end{array}$ \\
\hline $\begin{array}{l}\text { California Critical } \\
\text { Thinking } \\
\text { Disposition } \\
\text { Inventory (CCTDI), }\end{array}$ & $\begin{array}{l}\text { This scale has 7 subscales and consists of 75 questions. } \\
\text { The California Critical Thinking Scale (CCTDI) is known to have emerged in 1990 } \\
\text { as a result of the Delphi project organized by the American Philosophical Society. } \\
\text { The standardization study of the CCTDI was performed by Kökdemir (2003). The } \\
\text { scale, which adapted, consist of 51 questinos and 6 subscales } \\
\text { The highest total score is 306 points in this scale. According to this scale, having less } \\
\text { than 240 scores is defined as low critical thinking disposition, having a score between } \\
\text { 240 and 300 is defined as medium critical thinking } \\
\text { disposition and having more than 300 scores is defined as high critical thinking } \\
\text { disposition. }\end{array}$ \\
\hline \multicolumn{2}{|l}{} \\
\hline Source: Authors
\end{tabular}

\section{Statistical Analysis}

The statistical software of Statistical Product and Service Solutions 22.0 (SPSS) for Windows was used for analysis. A value of $p<0.05$ was considered statistically significant.

Variables which are determined by numerical measurements were expressed as arithmetic averages and standard deviations $(\mathrm{X} \pm \mathrm{SD})$ for descriptive analyses. A Mann Whitney test was used because the data didn't show a normal distribution.

\section{Results}

A total of 75 students, 44 females and 31 males, participated in the study. The ages of the participants ranged from 18 to 21 years old (table 3 ).

\begin{tabular}{|l|c|c|}
\hline Table 3: Properties of participants \\
\hline & $\begin{array}{c}\text { Creative Drama } \\
\text { Group }\end{array}$ & $\begin{array}{c}\text { Control } \\
\text { Group }\end{array}$ \\
\hline & $\mathbf{N = 1 0}$ & $19.7 \pm 0.8$ \\
\hline Age (years) $(\mathrm{X} \pm \mathrm{SD})$ & $19.8 \pm 1.08$ \\
(Min-Max) & $18-21$ & $18-21$ \\
\hline Sex n(\%) & $15(37.5)$ & $16(45.7)$ \\
Female & $25(62.5)$ & $19(54.3)$ \\
Male & & \\
\hline Source: Author &
\end{tabular}

According to the results obtained from the study; there was no significant difference between empathic tendencies, communication skills and critical thinking skills of individuals in both groups ( $p>0.05)$.

\begin{tabular}{|l|l|l|l|l|l|l|l|l|}
\hline Table 4: Comparison of groups \\
\hline \multicolumn{9}{|c|}{ Control Group } \\
\hline
\end{tabular}


When the creative drama group was compared in terms of gender, there was no significant difference between individuals' empathic tendencies, communication skills and critical thinking skills ( $>$ > 0.05). When the control group was compared in terms of gender, there was no significant difference between individuals' empathic tendencies, communication skills and critical thinking skills ( $p>0.05)$.

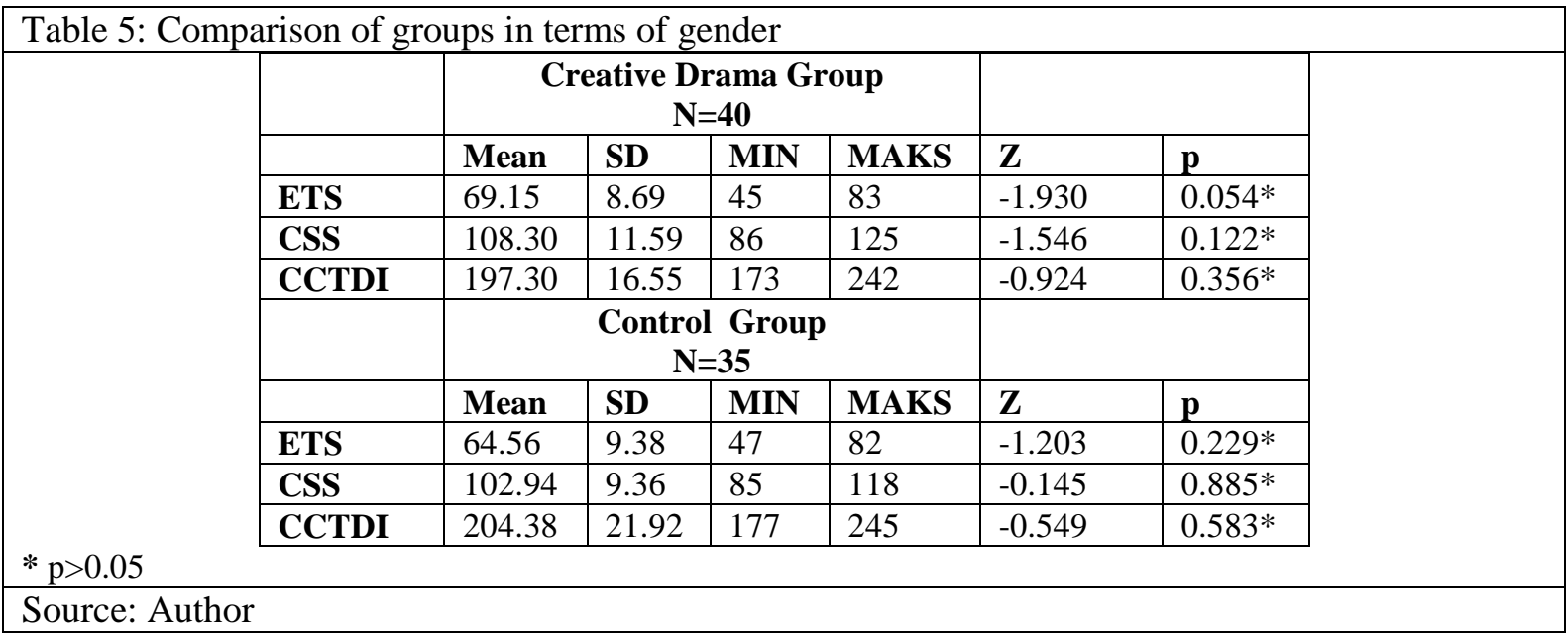

\section{Discussion}

In the study investigating the effectiveness of creative drama on the empathic tendency, communication skills, and critical thinking skills, no significant difference was observed in the groups participating in the 14-week creative drama activity and individuals in the control group. Uzunöz et al. (2017) stated that drama activities were effective on 4-year undergraduate teachers in the study that investigated the effectiveness of creative drama in the teacher's critical thinking skills. In addition, Giancarlo et al. (2001) stated that individuals who have a 4-year undergraduate education, increased their critical thinking tendencies. We believe that the individuals who participate in our study have low critical thinking skills because they are 1st-year students and they are at the beginning of their 4 years of undergraduate education.

Özçakır et al. (2016) reported that the welfare level influenced the empathic tendency in the study with which they investigated the relationship between the empathic tendencies of medical students and their welfare levels. In our study welfare levels were not compared in both groups. We think that there may be a difference in welfare levels, especially if there is no difference between the groups.

Sarmiento et al. (2017) found that psychology-based empathy training was effective on the empathic tendency in empathic tendencies of empathy education in nursing students. In our study general creative drama activities were used. We believe that the addition of special psychology-based activities to physiotherapy students may affect our work positively.

Freeman et al. (2010) stated that they could not find a significant difference in the study of the effects of creative drama on solving social problems. They stated that inter-group interactions and variables could reduce the impact of creative drama and these activities should continue for a long time, not for a period. In our study, we think that the 14-week creative drama activity may not be a sufficient enough period of time and this activity should continue throughout the entire undergraduate education.

Gupta et al. (2016) stated that parameters such as empathy and sensitivity would increase the quality of health. Throughout the undergraduate education, we believe that giving creative drama, empathy, communication and critical thinking training to all physiotherapy students may increase the quality of their health.

Chatterjee et al. (2017), in a study investigating clinical empathy in medicine, stated that women had a better empathic tendency than men. Over the years, a significant decrease in the empathic tendency of men, especially after 7th period can be seen. In our study, no difference was observed between the genders. We think that only the evaluation of freshman physiotherapy students is effective in not being found any different. We believe that differences between genders may be more meaningful in studies conducted with larger groups with different classes. 
Jeong et al. (2017) investigated the effects of communication skills on nurses' performances and stated that the performance of nurses with good communication skills was better. In our study, there was no significant difference between the communication skills between the groups. However, we believe that various programs should be added to the physiotherapy education curriculum in order to improve students' communication skills.

\section{Conclusion}

We believe that this study is a preliminary study on first-year physiotherapy students' empathic tendencies, communication skills and critical thinking skills. Particularly in the field of health, such studies are very few, therefore our study can give an idea for subsequent studies.

During the whole undergraduate education, students who have received creative drama training can improve performance.

Therefore, the evaluation of empathic tendency, communication skills, and critical thinking skills in different types of universities (government, foundation, etc.) and the evaluation of students in different cities can improve performance.

The empathic tendency, communication skills, and critical thinking skills can affect parameters such as gender, different years of education, and welfare levels. Therefore, studies that are conducted with more patients and are multi-centered should be done.

\section{References}

American Physical Therapy Association CAPTE (2013). The Commission on Accreditation in Physical Therapy Education Evaluative Criteria PT Programs. PT Evaluative Criteria.

Bas-Sarmiento, P., Fernández-Gutiérrez, M., Baena-Baños, M., \& Romero-Sánchez, J. M. (2017). Efficacy of empathy training in nursing students: A quasi-experimental study. Nurse education today, 59, 59-65.

Chatterjee, A., Ravikumar, R., Singh, S., Chauhan, P. S., \& Goel, M. (2017). Clinical empathy in medical students in India measured using the Jefferson Scale of Empathy-Student Version. Journal of educational evaluation for health professions, 14.

Dal Santo, L., Pohl, S., Saiani, L., \& Battistelli, A. (2014). Empathy in the emotional interactions with patients. Is it positive for nurses too?. Journal of Nursing Education and Practice, 4(2), 74.

DiMatteo, M. R., Sherbourne, C. D., Hays, R. D., Ordway, L., Kravitz, R. L., McGlynn, E. A., Rogers, W. H. (1993). Physicians' characteristics influence patients' adherence to medical treatment: results from the Medical Outcomes Study. Health psychology, 12(2), 93.

Dokmen, U. (1988) Measuring emphaty based on a new model and developing by psychodrama, Ankara University Journal of Faculty of Educational Sciences, 21(1), 155-190.

Fields S, Hojat M, Gonnella JS, Mangione S, Kane G, Magee M. Comparison of nurses and physicians on an operational measure of empathy. Evaluation and the Health Professions. 2004; 27: 80- 94.

Fields S, Mahan P, Tillman P, Harris J, Maxwell K, Hojat M. Measuring empathy in healthcare profession students using the Jefferson Scale of Physician Empathy: health provider-student version. Journal of Interprofessional Care. 2011; 25(4): $287-$ 93.

Fulford, J., Hutchinfs, M., Shmitz, H. (2001). Drama in primary education (Translated by: Leyla Küçükahmet, Hande Borçbakan, S. Sadi Karamanoğlu). Publishing: Nobel,Ankara

Freeman, G. D., Sullivan, K., Fulton, C. R. (2003). Effects of creative drama on self-concept, social skills, and problem behavior. The Journal of Educational Research, 96(3), 131-138.

Giancarlo, C. A., Facione, P. A. (2001). A look across four years at the disposition toward critical thinking among undergraduate students. The Journal of General Education, 50(1), 29-55.

Gupta, K. S., Rokade, V. (2016). Importance of quality in the health care sector: A review. Journal of Health Management, 18(1), 84-94.

Hojat, M., Erdmann, J. B., Gonnella, J. S. (2013). Personality assessments and outcomes in medical education and the practice of medicine: AMEE Guide No. 79. Medical teacher, 35(7), e1267-e1301.

Hojat, M., Gonnella, J. S., Mangione, S., Nasca, T. J., \& Magee, M. (2003). Physician empathy in medical education and practice: experience with the Jefferson Scale of Physician Empathy. In Seminars in Integrative Medicine (Vol. 1, No. 1, pp 25-41). WB Saunders.

Hojat, M., Louis, D. Z., Markham, F. W., Wender, R., Rabinowitz, C., \& Gonnella, J. S. (2011). Physicians' empathy and clinical outcomes for diabetic patients. Academic Medicine, 86(3), 359-364.

Kahriman, I., Nural, N., Arslan, U., Topbas, M., Can, G., Kasim, S. (2016). The effect of empathy training on the empathic skills of nurses. Iranian Red Crescent Medical Journal, 18(6).

Jeong, S. J., \& Kim, K. H. (2017). Empathy Ability, Communication Ability, and Nursing Performance of Registered Nurses and Nursing Assistants in Long-term Care Hospitals. Journal of Korean Academy of Nursing Administration, 23(3), 249-258. 
Kökdemir, D. (2003). Decision making and problem-solving under uncertainty. Unpublished doctorate dissertation, Ankara University, Institute of Social Science, Ankara.

Köksal-Akyol, A. (2003). Okul öncesi eğitimde drama ve örnek drama etkinlikleri. Okul öncesinde drama ve tiyatro, 63-76. Korkmaz, Ö. (2009). Teachers' critical thinking level and dispositions. Ahi Evran University Kırşehir Journal of Education, 10(1), 1-13.

Korkut Owen, F., \& Bugay, A. (2014). Developing a Communication Skills Scale: Validity and reliability studies. Mersin University Journal of the Faculty of Education, 10(2), 51-64.

Lake DA.(2003) Physical Therapy Admissions Requirements. Presented at: Academic Administrators Special Interest Group Meeting

Levent, T., (1999). Creating Drama Culture. Creative Drama in Theater in Education, Contemporary Drama Association Newsletter, 2, 7-9.

May, W. W., Morgan, B. J., Lemke, J. C., Karst, G. M., \& Stone, H. L. (1995). Model for ability-based assessment in physical therapy education. Journal of physical therapy education, 9(1), 3-6.

Ozcakir, A., Ediz, B., \& Bilgel, N. (2016). The relationship between subjective well-being and empathy among Turkish medical students. MedEdPublish, 5.

Uşakl1, H. (2007). Drama and communication skills. Publisher: Nobel, Ankara

Uzunöz, F. S., \& Demirhan, G. (2017). The effect of creative drama on critical thinking in preservice physical education teachers. Thinking Skills and Creativity, 24, 164-174.

Sternberg, P. (1998). Theatre for conflict resolution: In the classroom and beyond. Portsmouth, NH: Heinemann. 